\title{
Leopards in Western Turkey
}

\section{Markus Borner}

The leopard Panthera pardus tulliana survives in south-west Turkey, but after a two-month survey there for the World Wildlife Fund, the author shows that numbers are so small and the people's attitudes so hostile that this subspecies is probably doomed to extinction; leopards found in eastern Turkey are the Persian subspecies saxicolor. Other large predators are disappearing too, and the author urges the need to establish several large reserves, for which the Turkish Government's planned wildlife survey will provide the data.

The occurrence of the leopard in Western Anatolia is well documented in history. Reliefs showing leopards dating from about $6000 \mathrm{BC}$ were found near Konya, and leopards appeared on mosaics of early Christian times from Ayas. According to Cicero, the Anatolian leopard was used in the Roman circus, ${ }^{4,2}$ and various modern authors have described the occurrence and distribution of Panthera pardus tulliana in Turkey. ${ }^{1,4,5,6,2}$ In the south-west, south of a line between Izmir and Antalya, records were numerous, and there were reports also from the south and east. But recent reports are rare. The Turkish Department for National Parks and Wildlife was alarmed by the situation, and the World Wildlife Fund sent me on a two months' survey to investigate the leopard's status in western Turkey.

My first task was to interview several hundred villagers, herdsmen, hunters and forest officers. Between them these provided an abundance of information, but most of it dated back 20 to 30 years. However, I selected several areas from which there were reports of leopards within the previous five years, and visited these, with the help of the Forestry Department and the National Parks Department, recording animal tracks on transparent plastic with the help of a plexiglass plate, collecting faeces, and investigating factors such as hunting, agriculture and competition with domestic stock.

The results showed that the leopard has vanished from most parts of its former range in south-west Turkey as described by Kumerloeve, that is, south of a line between Izmir and Antalya. Around Izmir, where the last record was over ten years ago, there are no recent reports and it is probably extinct.

In the Samsun-da $\tilde{g}$ National Park south of Kuşadasi, the former Director of the Park, Mr Nuri Yetmişbeş, saw a leopard in 1972. In January and February 1975 a game warden saw leopard tracks; road workers and soldiers claim to have heard leopards at this time, and a horse was killed in the park, supposedly by a leopard. But there is no new information and I found no evidence of leopard in the field survey. As the park is rather small (11,000 ha) and surrounded by villages there seems to be no chance that any survive here. They have also vanished from the Ayden area, where they formerly occurred near the village of Erbeyli. The forest here has been cleared and no leopards survive.

The photograph above shows leopard habitat in the Besparmak mountains. $M$. Borner 


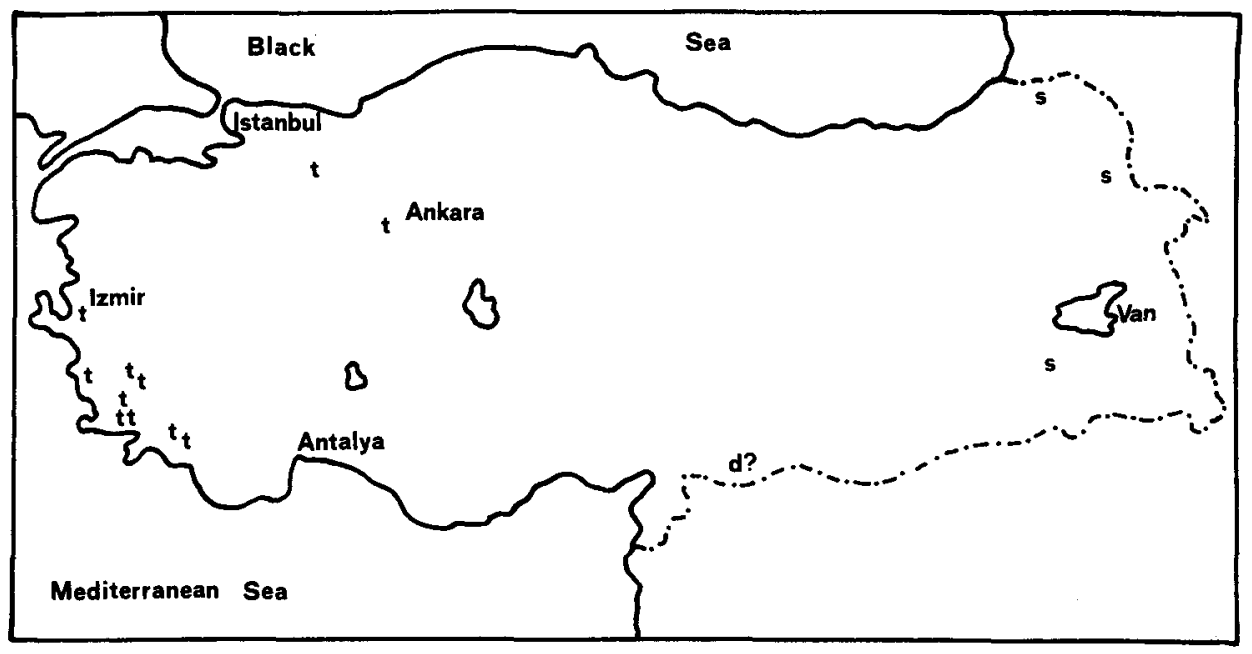

Places of origin of skins inspected during survey: $t$ Panthera pardus tulliana s $P . p$. saxicolor d P.p. dathei (not certain)

The Besparmak-dag was once a leopard stronghold, and new information suggested that the Besparmak mountains and their surroundings were the most likely area to find them. In 1974, between Ikistas and Ketendere, a leopard was poisoned, and in the spring of 1975 a leopard killed a cow near the village of Kacanci; villagers shot at the animal, but it escaped. In the spring of 1976, after several goats had been killed near the village of Viran, supposedly by a leopard, the mountain ridge was thoroughly searched but no evidence of leopard could be found. The chance that leopards survive in these mountains is very small.

The situation in the Gökbel-da $\tilde{g}$ is similar. These mountains are connected with the Besparmak mountains by a stretch of forest north of the village of Akovanlik. In 1975 a leopard was shot near Seferler, and in the spring of 1976 one was seen and shot at near Asar. In mid-September 1976 a mule was killed near Gökbel-Kö. Unfortunately it was two weeks before I heard of this, by which time no tracks were visible, as the area is used by cows and goats, but from the villagers' description it seems probable that it was a leopard that killed the mule. The area, however, is too small and reports too few for more than one or two animals to survive there.

In the Ilbera mountains (Labdaği), which harboured leopards until 10 or 20 years ago, many new forest roads are making the mountains easily accessible. Domestic goats are everywhere, and the leopard has vanished. The same applies to the Gök-Tebbe mountains, where leopards were hunted 20 to 30 years ago. Today roads are opening the area to farming and hunting, a new television antenna is being built on the mountain top, and the leopards have gone. North of Oren, where local names bear witness to the animal's occurrence, the last leopard was killed twelve years ago near the village of Mezgirk.

The Feth/Antalya area, where the last reports were about five years ago, was not surveyed; there is a slight possibility that a very few animals survive here.

\section{Reasons for Disappearance}

The main reason for the leopard's disappearance, as well as for the drastic decline of other wildlife, is overgrazing of the mountain and forest areas 

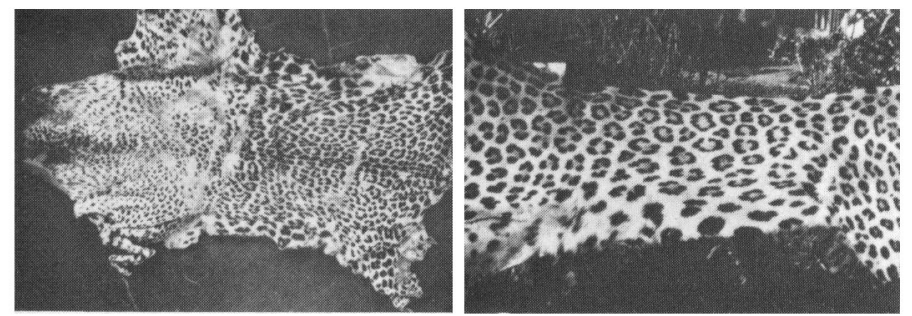

Left Panthera pardus tulliana from Ula, near Mug̃la, and a possible P.p. dathei

by domestic stock, especially goats. The natural prey species are becoming rare, due to competition by the goats, so that, like the wolf and the hyaena, leopards are increasingly dependent on domestic stock for food, and in constant conflict with the herdsmen and villagers. When villagers hear of a leopard or other predator in the neighbourhood, meat poisoned with Folidol is put out and everything done to shoot or trap the animal. The goats also destroy existing trees and prevent any natural forest regrowth, so that not only is the wildlife wiped out, but the Turkish Forestry Department suffers an enormous loss every year.

The second reason for the wildlife's disappearance is overhunting. The big predators - leopard, tiger, wolf, jackal, and hyena, as well as wild boar are not protected by law and can be hunted throughout the year without any restrictions. Most other wildlife is protected or can only be hunted at certain seasons, according to the Central Hunting Committee's decisions for the 1976/77 hunting season, although enforcement of these laws is nearly impossible. Hunting is regarded as the traditional right of every man and very popular.

The third reason for the leopard's decline is the opening up of the wilderness areas by new local and forest roads. Olive plantations replace the natural forest, new villages and gardens are built wherever there is water, and domestic goats are everywhere. Areas suitable for wildlife are vanishing rapidly.

\section{Leopard Subspecies}

It has been said that all leopards in Turkey belong to the same subspecies, Panthera pardus tulliana. I was able to inspect and measure five hides of leopards shot in south-west Turkey, and to study photographs of four more animals from the same area and also of one animal shot in February 1967 in the Bolu mountains; also the M.T.A. Museum had a stuffed leopard shot in Beypazari, near Ankara, in 1974. All these animals showed clearly the typical features of Panthera pardus tulliana. ${ }^{8}$ The general coloration is yellowish buff, with a touch of red, brownish on the back and pale on the belly. The large, widely spaced black rosettes extend all over the back, becoming solid dots directly behind the head and above the tail. The hair is about $1 \frac{1}{2}$ to $2 \mathrm{~cm}$ long on the back and 4 to $5 \mathrm{~cm}$ on the belly. The tail is as long as or longer than the body, and the hair on it is longer in the distal part than in the proximal, giving the last third of the tail a larger diameter than the proximal part. ${ }^{8}$

I was also able to inspect three leopard hides from eastern Turkey, one shot in 1971 in Eruh (near Siirt) by Mr Osman Giraud, and two collected by Professor Turhan Baytop, one in May 1970 in Kars (near Karakale) and the other in April 1972 in the Ararat mountains (Agri dagi). None of these were P.p. tulliana; all three showed the typical features of Panthera pardus 
Right Panther pardus

saxicolor from Siirt; the right-hand picture shows the hind part
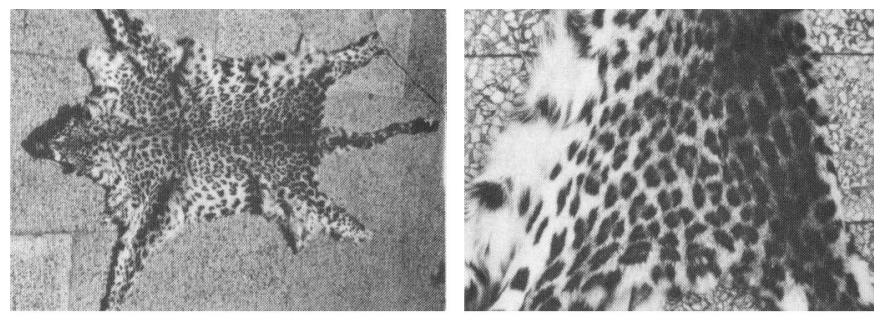

saxicolor, ${ }^{7}$ the most striking feature being their similarity to snow leopards. The hair is dense and long, reaching $7 \mathrm{~cm}$ on the belly; the general coloration is creamy white, being brown/yellow on the back and pure white on the belly; the rosettes are much smaller and closer together than in P.p. tulliana, with rows of solid dots extending along the back from head to tail, except in the middle where the small rosettes of the flanks extend over the back; the tail is shorter than the body, and lacks the thick end typical of P.p. tulliana. Zukowsky describes $P$.p. saxicolor as a subspecies of higher altitudes, occurring in northern Iran, which is mountainous like eastern Turkey. ${ }^{9,10,3}$

Finally I was able to see a skin found in the possession of Mr Nihat Tutan, from the National Parks Department, which shows the typical features of $P . p$. dathei, namely short hair, small open rosettes, all broken up in lines and dots, etc., as described by both Zukowsky and Kullmann. P.p. dathei is an animal of the hot deserts of Iran and Afghanistan. Unfortunately the origin of this hide is not known precisely, but it is suspected to have come from the south-east border of Turkey.

\section{Conclusions}

The conclusions to be drawn from this survey are that very few leopards survive in south-west Turkey, and that very little can be done for their conservation in view of their rarity and isolation, and the impossibility of stopping villagers from poisoning, shooting or trapping them. Moreover, as the leopards in eastern Turkey seem to belong to another subspecies, P.p. saxicolor, and that P.p.tulliana is only found in the south-west, the Anatolian leopard is very critically endangered.

To ensure the survival of Turkey's vanishing wildlife, a net of large reserves has to be created, where, as in the existing reserve near Antalya, hunting and domestic animals would be banned, but the forest would still be used by the Forestry Department. The National Parks Department and the Forestry Department are preparing a general survey of wildlife all over Turkey, which will provide the background data for the creation of such reserves. New laws concerning hunting and the grazing of domestic stock in forested areas are in preparation but have still to be passed by the government. Education and propaganda for the conservation cause is of paramount importance for the long-term survival of Turkey's wildlife.

\section{Summary}

No definite proof could be found that the leopard survives at all in southwestern Turkey; it is likely that a very few still exist, but they are probably doomed to extinction. The leopards of eastern Turkey are not the Anatolian subspecies of P.p. tulliana, but are the Persian subspecies P.p. saxicolor.

\section{Acknowledgments}

I wish to thank Mr Turhan Ugur, Vice Minister of Forestry, and Mr Hasan Asmaz, 
Director General of the National Parks and Wildlife Department, for providing cars and local assistance during the survey. I would like to thank Mr Turhan Akarca, who was very helpful during the first part, and Mr Osman Giraud who helped me in the second part of the survey.

\section{Bibliography}

1. BANOGLU, N. A. and BURR, M. 1953 Turkey, a Sportsman's Paradise, Ankara.

2. BAYTOP, T. 1973 Neue Beobachtungen über die Verbreitung des Kleinasiatischen Leoparden (P.p. tulliana) in der Turkei. Bonn. Zool. Beitr. 24: 183-184.

3. GUERPINAR

4. KULLMAN, E. 1967 Ueber Leoparden Afghanistans und ihre Parasiten. Freunde des Kölner Zoos Jahrg. 10, 4: 126-135.

5. KUMERLOEVE, H. 1956 Zur Verbreitung des Leoparden ( $P$. pardus L.) in Anatolien. D. Zool. Garten (NF) 22: 154-162.

6. KUMERLOEVE, H. 1957 Leoparden in Kleinasien Naturwiss. Rdsch. 10: 388.

7. KUMERLOEVE, H. 1971 Zum Stand des Vorkommens von Panthera pardus tulliana in Kleinasien.

8. POCOCK, R. J. 1930 The panthers and ounces of Asia. J. Bombay Nat.Hist. Soc. 34.

9. VALENCIENNES, M. A. 1856 Sur une nouvelle espèce de Panthère tuée par $M$. Tchihatcheff à Ninfi. C.R. Acad. Sci. Paris 42: 1035-1039.

10. ZUKOWSKY, L. 1959 Persische Panther. Der Zool. Garten (NF) 24: 329-344.

11. ZUKOWSKY, L. 1964 Weitere Mitteilungen über Persische Panther Der Zool. Garten (NF) 28: 151-182.

Dr Borner's survey was fully financed by World Wildlife Fund.

Seestrasse 167, CH 8800 Thalwil, Switzerland.

\section{Endangered Species in Finland}

The small population of wild woodland reindeer Rangifer tarandus fennicus in Finland, right on the eastern frontier with the USSR, are doing well according to Martti Montonen, and the protection of their breeding ground, Elimyssalo, is assured for at least the next five years. (See Oryx, January 1972, page 268.)

Eight mammals are considered endangered in Finland - i.e. their survival is threatened by human activities, according to P. Borg and K. K. Malmström. In addition to the woodland reindeer they are Alopex lagopus Arctic fox; Canis lupus wolf; Mustela lutreola European mink; Pusa hispida saimensis Saimaa ringed seal; Halichoerus grypus grey seal; Eliomys quercinus garden dormouse; Castor fiber beaver.

Seven more are vulnerable (likely to become endangered soon): Ursus arctos brown bear; Lutra lutra otter; Gulo gulo glutton; Pteromys volans flying squirrel; Myotis nattereri Natterer's bat; Plecotus auritus long-eared bat; and Erinaceus europaeus hedgehog.

Six species are rare (but not seriously threatened): Mustela putorius polecat; Lynx lynx lynx; Sicista betulina northern birch mouse; Myotis mystacinus whiskered bat; Myotis daubentonii water bat; Sorex minutissimus lesser pygmy shrew.

\section{The Role of Predators}

A revised edition of the valuable booklet Predatory Mammals in Britain is published by the Council for Nature and obtainable from the FPS office at 35p. FPS was one of the organisations concerned in its compilation. The new edition incorporates the changes effected by recent legislation. The concluding words of the booklet are printed in capital letters: 'Our native predators have an important role in nature and are of great scientific interest as well as giving pleasure to an increasing number of people. Thus the emphasis in most cases should be on prevention of damage rather than destruction of the predator'. 